\title{
Microbiological analysis of pasteurized and fresh fruit juice sold in Rawalpindi of Pakistan
}

\author{
S. A. Batool*, S. S. Tahir, N. Rauf and R. Kalsoom \\ Environmental Analytical Laboratory, PCSIR Sector H-9, Islamabad Pakistan
}

\begin{abstract}
Freshly prepared and pasteurized fruit juices sold by vendors in local market of Rawalpindi city from 10 locations were analyzed for the microbiological quality. Total viable count (TVC), total coliform, faecal coliform, molds and the presence of pathogenic microorganisms such as E. coli, Pseudomonas, Staphylococcus aureus, Salmonella, and fungi like Aspergillus, Pencillum, Rhizopus were determined .In open fruit juices available in city were highly contaminated with bacteria and fungi. E. coli, Salmonella, Staphylococcus, and Pseudomonas were isolated with different frequency. Aspergillus, Pencillum and Rhizopus were also found in juices especially Aspergillus was with high percentages. The pasteurized juices have less contamination as compared to the fresh juices samples. The number and type of microorganisms recovered from the freshly squeezed fruit juices made them unsafe for drinking. The results of this study demonstrate the unhygienic quality of popular types of market vended freshly squeezed fruit juices and their risk to the consumers.
\end{abstract}

Keywords: Fruit juices; Microorganisms; Contamination; Pasteurized; Aspergillus

\section{Introduction}

Juice is the liquid that is naturally enclosed in fruit or vegetable tissue. It is prepared by mechanically squeezing or macerating fruit or vegetable flesh without the application of heat or solvents and which are very nutritive, invigorating and non-alcoholic beverage, which is very popular throughout the world (Fruit juices regulation,England). It is important source of bioactive compounds such as phenolics (e.g. flavanone glycosides, hydroxycinnamic acids), vitamin $\mathrm{C}$ and carotenoid which is an excellent source of bio available antioxidant phytochemicals and it also helpful to improves blood lipid profiles especially the people affected with hypercholesterolemia (Franke et al., 2005). They are very scrumptious and palatable and they have most of the minerals like calcium, magnesium, phosphorus, and sodium and vitamins (FDA. 1999). Food security is a complex issue, which is influenced by a number of factors.

The Food and Agricultural Organization (FAO) of the United Nations and the World Health Organization (WHO) state that illness due to contaminated food is perhaps the most widespread health problem in the contemporary world (Edema, et al., 2005). In under develop countries juices are sold in the form of either in tetra pack which is pasteurized while streets vendors juices called as fresh juices which provide substantial amount of valuable nutrients at affordable. Most people can enjoy unpasteurized juice and drinks, however, for young children, the elderly and people with weakened immune systems, the effect can be severe or even deadly5. Most fruit juices contain sufficient nutrients that could support microbial growth. Several factors encourage, prevent, or limit the growth of microorganisms in juices; the most important are, $\mathrm{pH}$, hygienic practice and storage temperature and concentration of preservative (Esteve et al., 2005, Troller 1983).Researcher have concluded that carbonated beverages displace other nutritious beverages and are hazardous to the cardiometabolic and lipid profiles of children, adolescents and adults (Jay 1987, Bray 2010).

Water used for juice preparation can be a major source of microbial contaminants such as total coliforms, faecal coliforms, faecal streptococci, etc. Environmental formites may also make the fruits unsafe and these may have a role in spreading of Salmonella, Shigella, Vibrio, Escherichia coli, and other diseases causing as well as fruits spoilage types.

*Corresponding author. e-mail: afifahassan8@gmail.com 
Spoilage yeasts, such as Saccharomyces cerevisiae, Candida lipolytica and Zygosaccharomyces spp. can tolerate acidic environments (VanDam and Seidell, 2007). Epidemiological data indicate that cross-contamination during food preparation contributes notably to the occurrence of food-borne diseases. Cholera transmission was associated with consumption of street-vended beverages in Peru and Guatemala (ICMSF. 1980, Ries 1992). The unpasteurized juices have been shown to be a potential source of bacterial pathogens notably, Salmonella, E. coli O 157:H7(Koo et al., 1996, Ryu et al., 1998, Uljas et al., 1998)

The quality of juices is strictly maintained in developed countries under some law and regulation but in many developing and under developed countries like Pakistan, India, Bangladesh the manufacturer is not concern about the microbiological safety and hygiene of juices, therefore objective of the present study is to evaluate the quality of fresh and processed juices available in the Rawalpindi city, Pakistan.

\section{Material and methods}

Sample collection

630 samples of pasteurized juice and 100 street vendor juices were collected from 10 different location of Rawalpindi city (1). Chaklala Cantt (2). Allahabad (3). Westridge (4). Commercial market (5). Murree road, (6). Pirwadhee (7) Dhok Kashmiriyan (8). Ashgar mall road (9). Airport colony(10). Gulzar-e-Quid as shown in Fig. 1. The samples were collected aseptically and subjected to analysis of total viable count, coliforms count, fecal coliforms count, and mould count.

\section{Enumeration and isolation of bacteria.}

The determination of the total microbial contamination of the juice samples was performed fortnightly by the method by outlined in compendium of methods for the microbiological examination of foods (Zhuang et al., 1995). .For the determination of total viable count pour plate method was applied as describe by Morton, 2001. For coliforms and fecal coliforms MPN procedure was applied (AMPH and Morton R.D., 2001). For the detection of Salmonella spp., $25 \mathrm{~mL}$ samples were placed in sterile blender homogenized for 2 min in $225 \mathrm{~mL}$ of sterile Lactose broth (LB) and preenriched for $24 \mathrm{~h}$ at $35-37^{\circ} \mathrm{C}$. Subsequently, $1 \mathrm{~mL}$ of the pre- enriched culture was transferred to Selenite Cystine Broth (SC) and incubated for $18-24 \mathrm{~h}$ at $35-37^{\circ} \mathrm{C}$. In parallel, 0.1 $\mathrm{mL}$ of the pre-enriched culture was transferred into $10 \mathrm{~mL}$ of Heketonic enteric agar (HE) plates and incubated at 35 ${ }^{\circ} \mathrm{C}$ (Kornacki and Johnson, 2001).

\section{Enumeration and isolation of molds}

Mould counts were determined on Potato dextrose agar (PDA) plates. Plates were inoculated by spreading $0.1 \mathrm{~mL}$ of sample dilution on the surface of the agar and incubation was in the dark for 5-7 days at $25^{\circ} \mathrm{C}$. Fungal species were identified according to the colony morphology and acid staining (Wallace, Andrews et al., 2001 and Beuchat 2001).

\section{Statistical analysis}

Physico-chemical results have been statically analyzed for mean standard deviation using Excel Microsoft 2007. Data on the concentration of the food-borne pathogens was entered into Excel and transformed into $\log 10$ ColonyForming Units per $\mathrm{ml}(\mathrm{CFU} / \mathrm{mL}$ ) of food samples (Bergey, (1984).

\section{Results and discussion}

\section{Bacterial enumeration}

Obviously it is not recommended that all fruit juices can make up a major input to a diet, but they could certainly be recommended ahead of drinks like Coca-cola or Pepsi-cola. While fresh fruit juices are, by their very nature, exposed to the risk of contamination during preparation and are not subject to any preservative treatment prior to being drunk. It was for this reason that the same selection was examined for general microbial quality coliforms and yeast and mould count, as well as for specific pathogens. For that purpose a total of 730 juice samples in which 630 were pasteurized juices collected from shops and 100 open juices from, the street vendor were analyzed. All samples of pasteurized juices have showed low total plate count as it ranges from $0.00 \pm 0.00$ to $2.39 \pm 0.43 \log 10 \mathrm{cfu} / \mathrm{mL}$.

The recommended specifications for fruit juices sold in the Gulf Region are shown in Table I. The max mean count was found in Murree Road and no single colony of TVC were found in, Pirwadhee, Ashgar mall road, and Airport colony 
Tables I. The recommended microbiological standards for any fruit juices sold in the Gulf Region ${ }^{22}$

\begin{tabular}{lccc}
\hline Test & $\begin{array}{c}\text { Total Viable Count } \\
\left(\log _{10} \mathrm{cfu} / \mathrm{mL}\right)\end{array}$ & $\begin{array}{c}\text { Total coliforms } \\
\left(\log _{10} \mathrm{cfu} / \mathrm{mL}\right)\end{array}$ & $\begin{array}{c}\text { Yeast \& Mold } \\
\left(\log _{10} \mathrm{cfu} / \mathrm{mL}\right)\end{array}$ \\
\hline Maximum count anticipated & 3.669 & 1 & 2 \\
Max count permitted & 4.669 & 2 & 3 \\
\hline
\end{tabular}

as shown in Table II. On the other side the all open juices samples were contaminated with TVC, with the range of $3.19 \pm 1.34$ to $5.39 \pm 0.43 \log 10 \mathrm{cfu} / \mathrm{ml}$. The Maximum mean count was present in Murree road while the low count was found in Westridge and Ashgar mall road with mean count of $3.19 \pm 1.34$, and $3.82 \pm 0.67$ as shown in Table III. Our result revealed that the TVC present in pasteurized juices samples were in the permissible limits while in street vendor's juices it was high as compared to the recommend level. Our findings were closely showed agreement with the some previous studies that found the TVC in the juices samples were 5.176 to $8.778,2.0$ to 8.9913 .01 to $4.01 \log 10 \mathrm{cfu} / \mathrm{ml}$ respectively (Gulf Standards. 2000, Al-Jedah and Robinson, 2002 Shakir Uddin Ahmed et al., 2009). The presence of a very high TVC in local vendor's samples indicates serious faults in raw material selection, production hygiene, unsatisfactory sanitation and unsuitable storage temperature etc.

In all pasteurized juices samples the coliforms fecal coliforms were present but with very low count as minimum count was present in all location except high count was detected in Chaklala Cantt, Murree road and Gulzare-e-Quid with mean count of 0.00 while maximum count $1.44 \pm 0.47$
$1.28 \pm 0.59$, and $1.24 \pm 0.72 \log _{10} \mathrm{cfu} / \mathrm{mL}$. In open juice samples high count of coliforms fecal coliforms were present almost in all location. The max coliforms were found in Murree road with mean count of $3.28 \pm 0.59 \log _{10} \mathrm{cfu} / \mathrm{mL}$ and fecal coliforms with mean count of1.86 $\pm 0.48 \log _{10} \mathrm{cfu} / \mathrm{mL}$ as shown in Table III, which is higher than the recommended as shown in Table, I. The presences of coliforms are important in food as indicator of spoilage or potential pathogenic organism like E. coli, Salmonella, and Staphylococcus etc. It is found that the high contamination of juices found in Murree road which contended that the unhygienic location of the shops namely heavy vehicular traffic near bus station.

\section{Yeast and molds}

Yeast and molds are common contaminants present in food especially in juices. The mean count of yeast and mold found in open street juice samples were $6.60 \pm 0.52,4.71 \pm 1.49$, 4.76 \pm 1.09 , and 3.62 \pm 0.19 in location Allahabad, Pirwadahe, Murree Road, Westridge which is higher as compared to recommended level shown in Table I, while in pasteurized juices it was detected with mean count of $3.46 \pm 0.69$, $3.23 \pm 0.53,3.19 \pm 0.34$ in location Chaklala Cantt, Dhok

Table II. Microbiological contamination in pasteurized fruit juices sold in Rawalpindi city

\begin{tabular}{|c|c|c|c|c|c|}
\hline & \multirow[t]{3}{*}{ No of samples } & TVC & Coliform & Fecal. Coli & Yeast\&molds \\
\hline & & $\left(\log _{10} \mathrm{cfu} / \mathrm{mL}\right)$ & $\left(\log _{10} \mathrm{cfu} / \mathrm{mL}\right)$ & $\left(\log _{10} \mathrm{cfu} / \mathrm{mL}\right)$ & $\left(\log _{10} \mathrm{cfu} / \mathrm{mL}\right)$ \\
\hline & & Mean \pm SD & Mean \pm SD & Mean \pm SD & Mean \pm SD \\
\hline Chaklala cantt & 63 & $1.17 \pm 0.43$ & $1.44 \pm 0.47$ & $0.2 \pm 0.44$ & $3.19 \pm 0.34$ \\
\hline Allahbad & 63 & $2.00 \pm 0.51$ & $0.83 \pm 1.04$ & $0.95 \pm 0.89$ & $2.76 \pm 1.09$ \\
\hline Westridge & 63 & $2.19 \pm 1.34$ & $0.62 \pm 1.43$ & $0.51 \pm 0.81$ & $2.07 \pm 0.42$ \\
\hline Commercial market & 63 & $2.26 \pm 0.57$ & $0.61 \pm 0.63$ & $0.31 \pm 0.58$ & $2.71 \pm 1.49$ \\
\hline Muree road & 63 & $2.39 \pm 0.43$ & $1.28 \pm 0.59$ & $0.86 \pm 0.48$ & $2.60 \pm 0.52$ \\
\hline Pirwadahee & 63 & $0.00 \pm 0.00$ & $0.00 \pm 0.00$ & $0.00 \pm 0.00$ & $0.00 \pm 0.00$ \\
\hline Dhok Kashmiryian & 63 & $2.33 \pm 0.56$ & $1.07 \pm 0.65$ & $0.58 \pm 0.27$ & $3.46 \pm 0.69$ \\
\hline Ashgar mall road & 63 & $0.00 \pm 0.00$ & $0.00 \pm 0.00$ & $0.56 \pm 0.32$ & $1.01 \pm 0.05$ \\
\hline Airport colony & 63 & $0.00 \pm 0.00$ & $0.00 \pm 0.00$ & $0.00 \pm 0.00$ & $0.00 \pm 0.00$ \\
\hline Gulzar-e-quid & 63 & $1.06 \pm 0.62$ & $1.24 \pm 0.72$ & $0.9 \pm 0.63$ & $3.23 \pm 0.53$ \\
\hline
\end{tabular}


Kashmiriyan, and Gulzare-e-Quid as shown in Table II and III. Susceptibility of fungi in fruits and vegetables is largely due to differential chemical composition. The higher $\mathrm{pH}$ (near neutrality) and moisture contents are associated with their greater predisposition to fungal spoilage. The occurrence of fungal spoilage of fruits is also recognized as a source of potential health hazard to man and animals. This is due to their production of mycotoxins (naturally occurring toxic chemical often of aromatic structure compounds which are capable of including mycotoxicoses in man following ingestion or inhalation. They differ in their degree and manner of toxicity. The contamination of fruits and vegetables by fungi could also be as a result of poor handling practices in food supply chain, storage conditions, distribution, marketing practices and transportation (Elmahmood et al., 2007).

\section{Isolation of bacteria}

We isolated different species of bacteria from pasteurized and open juice samples in which E. coli, Salmonella, Staphylococcus and Pseudomonas were present. E. coli is genus of gram negative facultative bacteria. It has been noted for its acid adaptive and acid tolerant properties in a number of foods under variety of condition. Some earlier research showed that its important pathogens that causing haemolytic uremic syndrome in human beings. Our result indicated that the open juices were highly contaminated with these pathogens as compared to the pasteurized juices available in shops as shown in Figs. 2 and 3. E. coli was present in $1.43 \%$ only in samples of Allahabad and Murree road, while in street vendor juices were highly contaminated especially in Murree road with $50 \%$. A number of factors are responsible for contamination of freshly fruit juices especially contaminated water, utensils, and fruit which is already contaminated by microorganism. Previously studies showed the presence of E. coli, Salmonella and Staphylococcus aureus in street vendor juices our result showed similarities with them (Griffin and Tauxe, (1991 Joy Lewis et al., 2006, and Durgesh et al., 2008). Salmonella causes many diseases in animals especially typhoid fever in human. Isolation of Salmonella from juices samples is of public health concern because it is zoonotic agent and it causes typhoid fever in human beings.

According to our findings Salmonella was present in pasteurized juices with $1.25,2.50$ and $1.43 \%$ in location Westridge Muree road and Gulzar-e-quid, while in open juices it was found in location Allahbad Westridge Muree road Pirwadahee, and Dhok Kashmiryian with percentage of $50,20 \%$ as shown in Figs. 1 and 2. Some recent studies account the presence of different Salmonella Species in fresh fruit juices (Shakir Uddin Ahmed et al., 2009).

The Staphylococcus were present in open juices samples were , 60, 50 and 40\%in location 3,4,and 5 while in pasteurized juices it was detected with high $36.65 \%$ in location 5 which is much lower as compared to the open juices samples. It is typical pathogens that is mostly present in the mucus membrane of warm blood animals especially in human the main source of transmission of $S$. aureus in juices

Table III. Microbiological contamination in street vendor fruit juices sold in Rawalpindi city

\begin{tabular}{|c|c|c|c|c|c|}
\hline & No of samples & $\begin{array}{l}\text { TVC }\left(\log _{10}\right. \\
\text { cfu/mL) } \\
\text { Mean } \pm \text { SD }\end{array}$ & $\begin{array}{c}\text { Coliform } \\
\left(\log _{10} \mathrm{cfu} / \mathrm{mL}\right) \\
\text { Mean } \pm \mathrm{SD}\end{array}$ & $\begin{array}{c}\text { Fecal. Coli } \\
\left(\log _{10} \mathrm{cfu} / \mathrm{mL}\right) \\
\text { Mean } \pm \text { SD }\end{array}$ & $\begin{array}{c}\text { Yeast \& molds } \\
\left(\log _{10} \mathrm{cfu} / \mathrm{mL}\right) \\
\text { Mean } \pm \mathrm{SD}\end{array}$ \\
\hline Chaklala cantt & 10 & $3.17 \pm 0.43$ & $2.44 \pm 0.47$ & $0.20 \pm 0.44$ & $3.19 \pm 0.34$ \\
\hline Allahbad & 10 & $3.01 \pm 0.51$ & $1.83 \pm 1.04$ & $0.95 \pm 0.89$ & $4.76 \pm 1.09$ \\
\hline Westridge & 10 & $3.19 \pm 1.34$ & $1.62 \pm 1.43$ & $0.51 \pm 0.81$ & $3.07 \pm 0.42$ \\
\hline Commercial market & 10 & $3.26 \pm 0.57$ & $1.61 \pm 0.63$ & $0.31 \pm 0.58$ & $4.71 \pm 1.49$ \\
\hline Muree road & 10 & $5.39 \pm 0.43$ & $3.28 \pm 0.59$ & $1.86 \pm 0.48$ & $6.60 \pm 0.52$ \\
\hline Pirwadahee & 10 & $4.39 \pm 0.20$ & $2.21 \pm 0.55$ & $0.56 \pm 0.26$ & $3.62 \pm 0.19$ \\
\hline Dhok Kashmiryian & 10 & $3.33 \pm 0.56$ & $2.07 \pm 0.65$ & $0.58 \pm 0.27$ & $3.46 \pm 0.69$ \\
\hline Ashgar mall road & 10 & $3.82 \pm 0.67$ & $1.75 \pm 0.58$ & $0.56 \pm 0.32$ & $3.06 \pm 0.62$ \\
\hline Airport colony & 10 & $3.21 \pm 0.41$ & $1.81 \pm 0.92$ & $0.76 \pm 0.52$ & $3.85 \pm 0.38$ \\
\hline Gulzar-e-quid & 10 & $3.06 \pm 0.62$ & $2.24 \pm 0.72$ & $0.9 \pm 0.63$ & $3.23 \pm 0.53$ \\
\hline
\end{tabular}




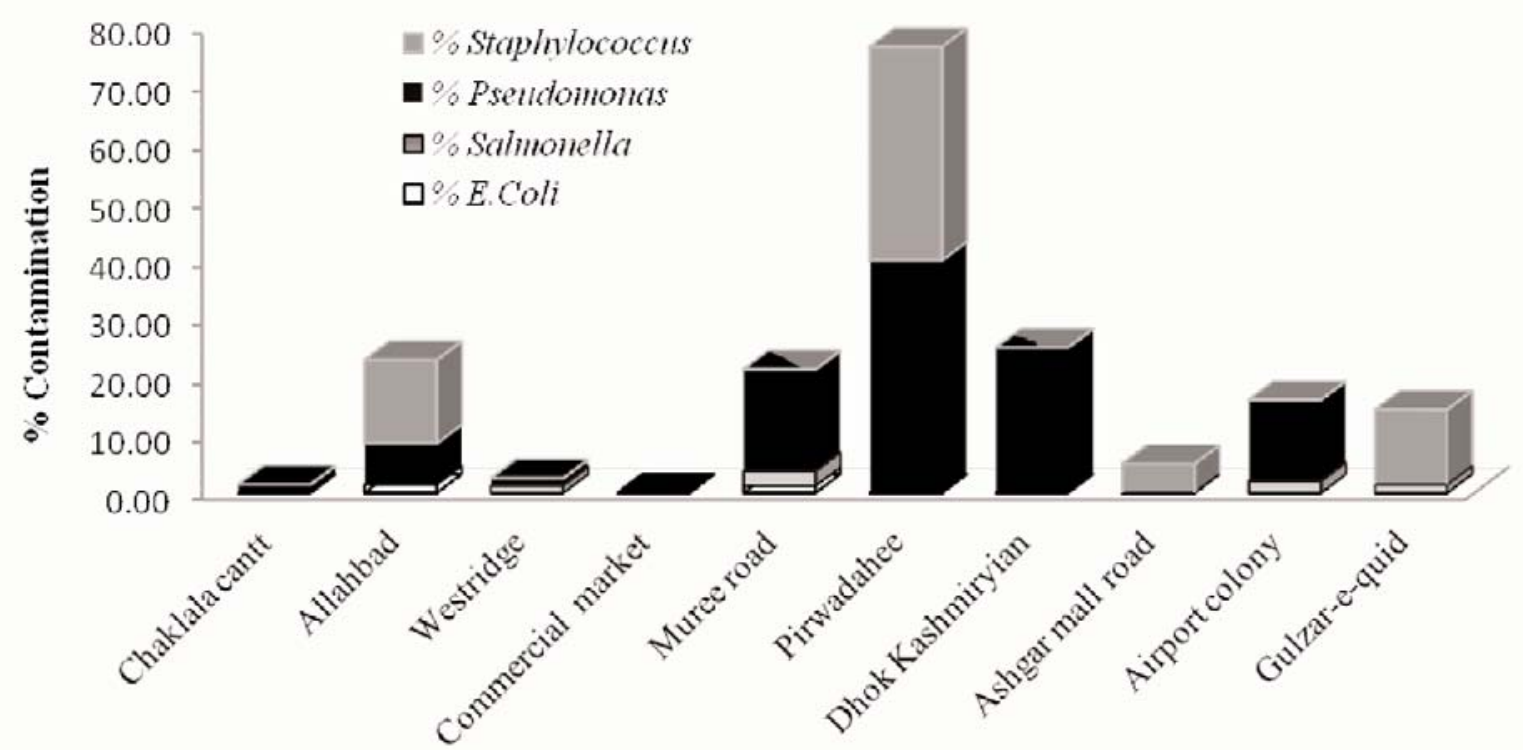

Fig. 1. Bacterial contamination \% isolated from pasteurized juice samples

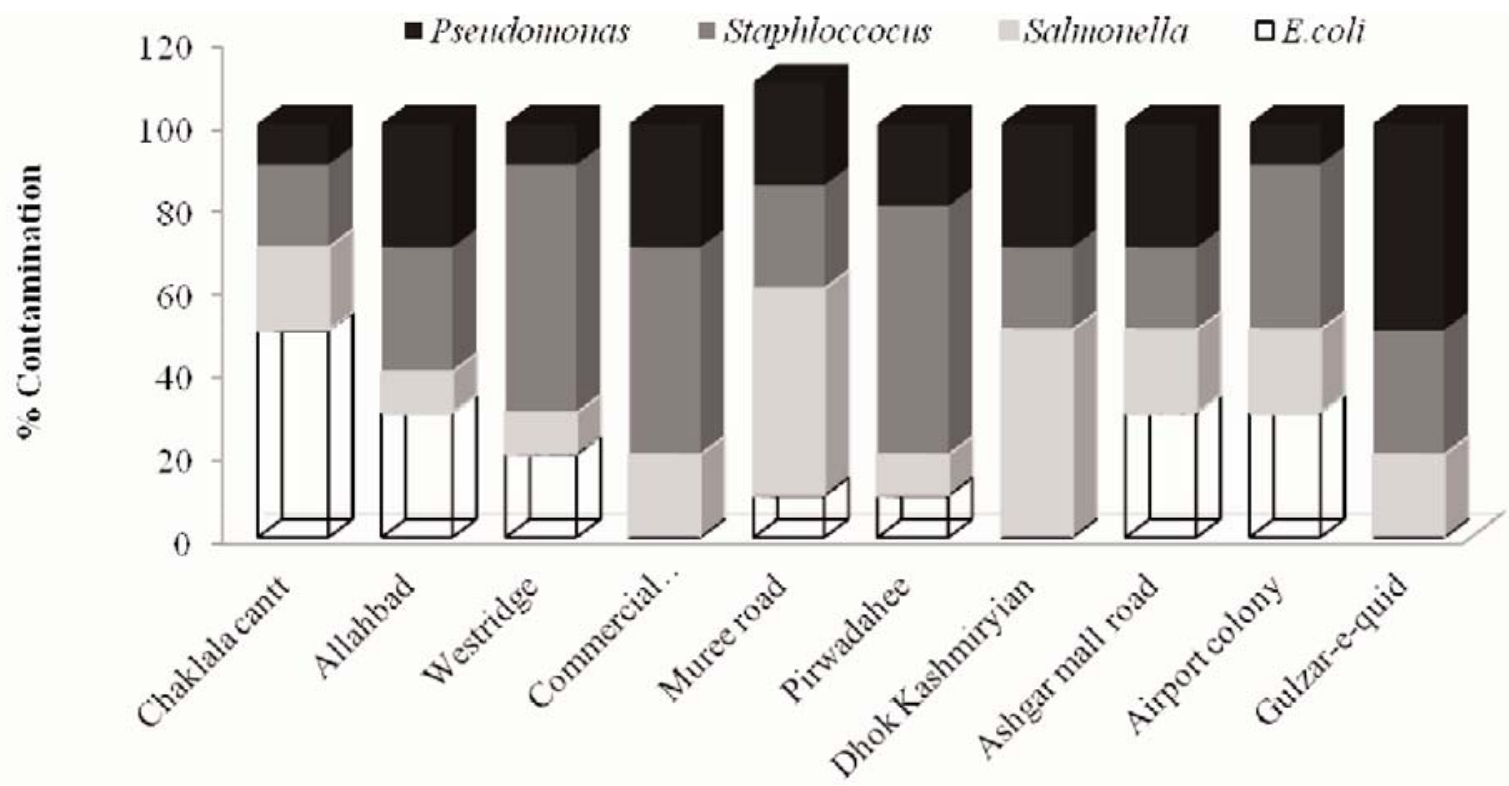

Fig. 2. Bacterial contamination in fresh juice samples collected from street vendor

is during processing of juices and illiterate people which did not careful about hand and utensil washing. In food product it should be in lower number because it produces toxin which causes gastroenteritis syndrome in human especially in children and immunocompromised patient and it cannot be destroy by heating, drying or freezing.

Pseudomonas is an environmental contaminant commonly originating from water sources. According to current research in open juices samples it was present high in $\%$ as compared to the pasteurized juices samples. In street available juices it was present 50,30,\% in locations, $2,4,7,8$ and 10 while on the other side in bottle juices maximum $60 \%$ was present in location 6 . The presence of Pseudomonas indicate that the water pipes lines contaminated with the microorganism and use of water from these pipes lines to clean the equipments may lead to high Pseudomonas count . 


\section{Fungal isolates}

In our recent studies we isolated the fungi species from all contaminated juice samples in which Aspergillus, Pencillum and Rhizopus. In pasteurized juices Aspergillus is maximum present with $90 \%$ in location 10 while Rhizopus were present $10 \%$ with min count as shown in Figs. 3 and 4.
Aspergillus flavaus is the main source of mycotoxin productions in the world's food supplies, while Pencillum were recorded the second point of research in juices mostly it will come from mechanical cleaning of fruits but they are not pathogenic. Moisture content in cereal or flour is the most important factor that causes the molds and yeast growth. Mould contamination on juices, which can exist at the farm

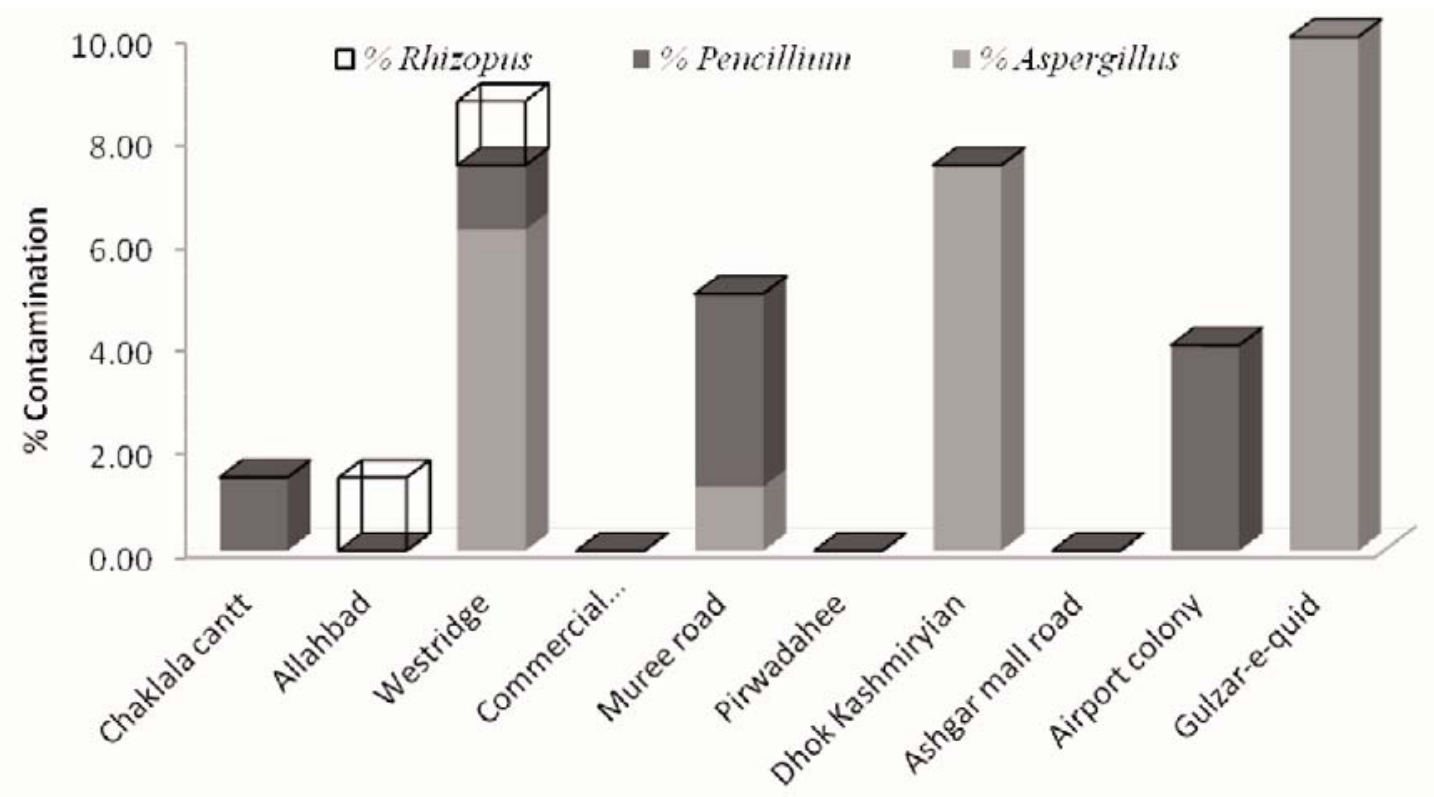

Fig. 3. Fugal contamination in Pasteurized juices samples collected from shops

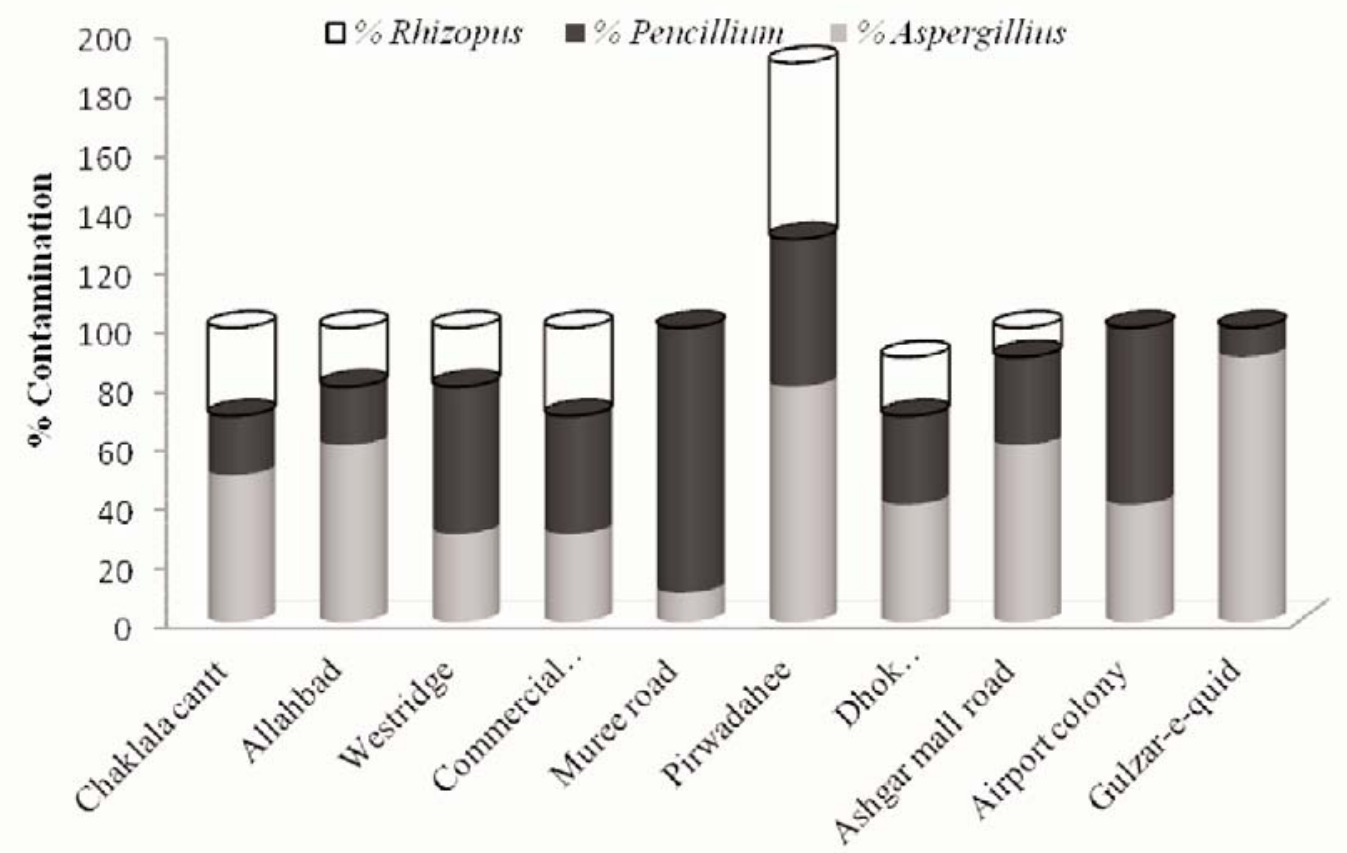

Fig. 4. Fugal contamination in fresh juices sample collected from street vendo 
or at the site of storage, affects the yield, quality, and nutritional value of the products. Fungi were also identified in all fresh or pasteurized juice samples as reported by some prior studies (Akinmusire, 2011 Faten et al., 2011, De Donno et al 1998 and Almas et al., 2010).

From the results obtained in the present study, it finds that post-harvesting handlings such as the preparation steps by the hawker stalls are poor. Many hawkers are unaware of the importance of good sanitary procedures and the food safety levels. Most fresh fruits are washed with un-chlorinated water and all fruits are cut and blended using the same utensils without cleansing in between. Chlorinated or electrolyzed water can help to sanitize and decontaminate against food borne pathogen of fresh fruits prior to consumption. Washing with running water can help to remove soil and dirt from the fresh fruits.

\section{Conclusion}

The microbial loads of most of the fruits juices were higher than the specifications set for fruit juices sold in the Rawalpindi areas. It was concluded that due to unhygienic fruit handling in the unsanitary environmental conditions under which the vendors operate the juices become contaminated with harmful bacteria and fungi. Vendors did not have proper attire and they did not use a sanitized glove. Measures to curb the lack of knowledge, education and exposure of these hawkers to proper food safety procedures are hence urgently needed. Thus, high level of workers hygiene should be enforced and the use of disinfectant better practiced to improve the microbial quality, safety, and shelf-life of final product.

\section{References}

Almas A, Shahnaz D and Marium T (2010), Mycoflora associated with sugar cane juice in Karachi city. Pak. $J$. Bot. 42(4): 2955-2962.

AMPH (2001), Compendium of methods for the microbiological examination of foods. Washington, DC: American Public Health Association. Morton R.D., 2001. Aerobic plate count,.In: Microbiological Examination of Foods, (Eds. PF Downes, K Ito), American Public Health Association, Washington D.C. 63-67.

Al-Jedah JH and Robinson RK (2002), Nutritional Value and Microbiological Safety of Fresh Fruit Juices sold through Retail Outlets in Qatar. Pakistan J. Nutri. 1 (2): 79-81.
Aran N and Eke D (1987), Mould mycoflora of some Turkish cereals and cereal products. MIRCEN Journal. (3): 281-287.

Akinmusire OO (2011), Fungal Species Associated with the Spoilage of Some Edible Fruits in Maiduguri Northern Eastern Nigeria Advances in Environmental Biology, 5(1): 157-161.

Bray GA (2010), Soft drink consumption and obesity: it is all about fructose. Current Opinions in Lipidology. 21: 51-7.

Beuchat LR and MA cousin (2001), Yeast and Molds.In: Microbiological Examination of Foods, (Eds). PF Downes, K Ito, American Public Health Association, Washington D.C. 209-213.

Bergey SA (1984),.Bergey, Manual of Determinative Bacteriology, 9th edition, Williams \& Wilkins., Philadelphia.

Caulcutt R and Boddy R (1983), Statistics for Analytical Chemist, Chapman and Hall Ltd,New York.

Durgesh P, Mahale Ranjana G, Khade Varsha K, Vaidya, (2008). Microbiological Analysis of Street Vended Fruit Juices from Mumbai City, India. Internet. J. Food Safety. 10: 31-34.

Diana JE, Pui CF and Son R (2012), Enumeration of Salmonella spp., Salmonella Typhi and Salmonella Typhimurium in fruit juices Inter. Food. Res. J. 19(1): 51-56.

De Donno A, Montagna MT, Erroi R, Liaci D, Sanapo S and Caggiano G (1998). Food products and fungal contamination. Note II. Study on moulds presence in pasteurized and fresh fruit juices. J. Pre. Medi. Hyg. 39: 71-73.

Edema MO, Omemu AM and Bankole MO (2005), Microbiological safety and quality of ready-to-eat foods in Nigeria. In: the Book of Abstract of the 29th Annual Conference \& General Meeting on Microbes As Agents of Sustainable Development, organized by Nigerian Society for Microbiology (NSM), University of Agriculture.

Esteve MJ, A Frigola and FO Samuel (2005), Chemical and storability of fruit flavoured Drink.World. J. Agric. Sci. 1: $165-168$.

Elmahmood AM and Doughari JH (2007), Microbial quality assessment of kunun-zaki beverage sold in Girei 
town of Adamawa State, Nigeria. African J. Food. Science. 011-015.

Effiuvwevwere BJO (2000), Microbial Spoilage Agents of Tropical and Assorted fruits and Vegetables (An Illustrated References Book). Paragraphics publishing company, Port Harcourt.1-39.

Faten S, Mansour, Khaled S, Nagy, Amal A, Taqi and Kasim Abass Aska, (2011), Factors affecting the fungal contamination of some fruit juices packaged in Tetra Pak. African. J. Biotech. 10(60): 12957-12962.

Fruit Juices and Fruit Nectars (England) Regulations.

Franke AA, Cooney RV, Henning SM and Custer LJ (2005), Bioavailability and antioxidant effects of orange juice components in humans. J Agric. Food. Chem. 53(13):5170-8.

FDA (1999), Fruit morphology and composition. Center for Food Safety and Applied Nutrition United States Food and Drug Administration. Available at: http://vm.cfsan. fda.gov/ comm/ juicback.html. Accessed 06 August 2007.

Gulf Standards. (2000), Microbiological Criteria for Foodstuffs-Part 1. GCC, Riyadh, Saudi Arabia.

Griffin PM and Tauxe RV (1991), The epidemiology of infection caused by Escherichia coli O157:H7,other enterohemorrhagic E. coli and associated haemolytic uremic syndrome. Epidemiol. Rev. 13: 60-98.

H.Wallace, Andrews, Russell S Flowers John Silliker and J. Stan Bailey (2001), Salmonella. In: Microbiological Examination of Foods, (Eds. PF Downes, K Ito), American Public Health Association, Washington, D.C.

ICMSF (1980), Microbial Ecology of Foods. Factors Affecting Life and Death of Microorganisms, 311. International Commission on Microbiological Specification for Foods (ICMSF). Academic Press, Orlando.

Joy E, Lewis, Patrina Thompson B.V.V.B.N.,Rao, C. Kalavati, and Rajanna B (2006), Human Bacteria in Street Vended Fruit Juices:A Case Study of Visakhapatnam City, India. Internet. J. Food. Safety. 8: 35-38.

Jay JM (1987), Modern Food Microbiology, 3rd edn, 641. CBS Publishers \& Distributors, New Delhi.
Kornacki JL and JL Johnson (2001), Enterobacteriacea, coliforms and Escherichia coli as quality and safety indicators. In: Microbiological Examination of Foods, (Eds. PF Downes, K Ito), American Public Health Association, Washington D.C. 69-80.

Koo D, Aragon A, Moscoso V, Gudiel M, Bietti L and Carrillo N (1996), Transmission of a newly introduced epidemic strain by street vendors. Epidemiol Infect. 116: $121-6$.

Morton RD (2001), Aerobic plate count, ().In: Microbiological Examination of Foods, Eds. PF Downes, K Ito, American Public Health Association, Washington D.C. 63-67.

Ries AA, Vugia DJ, Beingolea L, Palacios AM, Vasquez E, Wells JG (1992), Cholera in Piura, Peru: a modern urban epidemic. J. Infect. Dis. 166: 1429-33.

Ryu JH and Beuchat LR (1998), Influence of acid tolerance responses on survival, growth, and cross- protection of Escherichia coli O157:H7 in acidified media and fruit juices. Int. J. Food Microbiol. 45: 185-93.

Shakir Uddin Ahmed., M. Tania Nasreen, Badrunnessa Feroza and Sahana Parveen (2009), Microbiological Quality of Local Market Vended Freshly Squeezed Fruit Juices in Dhaka City, Bangladesh. Bangladesh. J. Sci. Ind. Res. 44(4): 421-424.

Troller JA (1983), Sanitation in Food Processing. Academic Press, Inc, New York.

Uljas HE and Ingham SC (1998), Survival of Escherichia coli 0157:H7 in synthetic gastric fluid after cold and acid habituation in apple juice or trypticase soy broth acidified with hydrochloric acid J. Food Pro. 61: 93947.

VanDam RM and Seidell JC (2007), Carbohydrate intake and obesity. European Journal of Clinical Nutrition, 61: 75-99.

Zhuang R, Beuchat LR and Angulo FJ (1995), Fate of Salmonella montevideo on and in raw tomatoes as affected temperature and treatment with chlorine. Appl Environ Microbiol 61: 2127-31.

Received: 10 February 2012; Revised: 02 June 2013; Accepted: 08 July 2013. 